\title{
The Preliminary Study Of The New Responsibility Accounting
}

\author{
Yan Zhang ${ }^{1}$, Yulin Xia ${ }^{1}$ \\ ${ }^{1}$ The engineering technical college of chengdu university of technology, China
}

Keywords: the new responsibility accounting, decentralized management, accounting system, the economic responsibility

\begin{abstract}
With the arrival of information age, new economy responsibility accounting is undoubtedly of enterprise, to strengthen the process control and implement target management, foreign enterprise competitiveness, increase the enterprise value of an effective control method. But the traditional responsibility accounting in a relatively stable economic environment and development, must be in a dynamic and changeable business environment, and according to the new characteristics of modern enterprise management, to adapt to the enterprise organizational change and the specific needs of internal management, integration of modern information technology advantages, to meet the requirements of the responsibility accounting in the new century and new responsibility accounting.
\end{abstract}

\section{Introduction}

With the arrival of information age, new economy responsibility accounting is undoubtedly of enterprise, to strengthen the process control and implement target management, foreign enterprise competitiveness, increase the enterprise value of an effective control method [1]. But the traditional responsibility accounting in a relatively stable economic environment and development, must be in a dynamic and changeable business environment, and according to the new characteristics of modern enterprise management, to adapt to the enterprise organizational change and the specific needs of internal management, integration of modern information technology advantages, to meet the requirements of the responsibility accounting in the new century and new responsibility accounting.

\section{The importance of the new responsibility accounting}

Responsibility accounting is a subsystem of management accounting. It is under the condition of decentralized management, in order to adapt to the requirements of economic responsibility system, the enterprise internal establish accountability unit, and shall be responsible for their division of labor in the economic activities of planning, control, evaluation and performance evaluation of a set of accounting system [1]. Essentially it is the enterprise to strengthen internal management responsibility and implementation of an internal control system, is to make the accounting information associated with closely related responsibility units at all levels of information control system.

Set up responsibility accounting, clear responsibility content is for the sake of the economic management accounting data with responsible, combine their hats, forcing them to take responsibility, encourage them to work actively, so that the huge economic organization to divide and rule, give full play to the positive role of the masses.

To implement responsibility accounting is the need of deepening the reform of enterprise, also is the deepening of reform, accounting is an inevitable trend in the reform. Responsibility accounting is to increase economic benefits as the center, highlight the responsibility accounting, control, responsibility assessment and combined with the distribution system of new form of management accounting. Responsibility accounting can adapt to the development of the socialist economic relationship, can adapt to the development of social production, can adapt to carry out the principle of distribution according to work [1]. In comprehensive reform of economic system, introduce the competition mechanism under the conditions of enterprises, implement responsibility accounting and 
further distinguish responsibility, calculation results, determine the rewards and punishments, is the inevitable trend in the reform.

Responsibility accounting is helpful to establish and consolidate and improve the enterprise economic responsibility system. Responsibility accounting is the foundation of enterprise economic responsibility system; it is an important part of it [1]. Required by the enterprise economic responsibility system itself according to the economic responsibility accounting, control and assessment; Clear division of economic responsibility, do their duties and clear; Income distribution and economic benefits received and so on, cannot leave the responsibility accounting, enterprises only completes the responsibility accounting management work, to consolidate and enrich the economic responsibility system.

\section{The characteristics of the new responsibility accounting}

The characteristics of the new responsibility accounting are mainly manifested in the following aspects [2]:

The new responsibility accounting is a part of the management accounting. New responsibility accounting must through the establishment of responsibility entity, implement target management, budget management and the margin analysis and control method in advance, matter of accounting, help enterprise overall goal realization.

The new responsibility accounting on the premise and the core responsibilities clear. Responsibility accountings in the economic responsibility entity are the prerequisite, the methods of accounting, the accounting and management, to determine the situation and effect of responsibility entities. Starting from the "responsibility", responsibility accounting is completely different from forecasting in financial accounting and managerial accounting, accounting for decision making.

The new responsibility accounting is the enterprise comprehensive value accounting. Responsibility accounting is full, all-round, the whole process of all-round value accounting value accounting, is includes professional accounting also includes the accounting of accounting. This requires the enterprise to organize the responsibility unit staff full value accounting, consciously control the preparation of responsibility budget, implementation of responsibility, with the full process of responsibility and self assessment.

The new responsibility accounting is an effective control of modern enterprise management mode. Responsibility accounting is based on the basic characteristics of modern enterprise system "well-defined power and responsibility, scientific management". And to implement the responsibility appraisal indicators to the responsible units, rewards and punishments and clear, clear responsibility and power, and stimulates the responsible units play an active initiative, make the enterprise overall goal is the basis of the implementation and guarantee. These are the purpose and requirements of modern enterprise system.

\section{Using the problems existing in the responsibility accounting in enterprises}

The problems in the process of divided responsibility unit. Enterprises in the process of divided responsibility unit, tend to follow the western responsibility accounting mode, the enterprise interior organization units is divided into "three responsibility center", namely, cost center, profit center and financial center as the main body of responsibility accounting. The three responsibility center respectively only on controllable costs, natural or man-made, capital usage is responsible for the unit [2]. This one is not fully embody management tenet and effect; The second is not responsibility for each unit to conduct a comprehensive assessment; 3 it is to do not conform to the actual situation of the enterprise.

The problems in the process of implement the responsibility indicators. First, the responsibility indicators are the establishment of a fair enough. Different responsibility unit of the nature of the work, the comparison of performance between the scale of the lack of unified, the same target completion does not mean the same contribution for the enterprise, it is difficult to make all departments are fair and reasonable, is not fully mobilize the enthusiasm, initiative and creativity of 
the labor force. Second, responsibility index generally adopts the combination of make up and down; all responsible units in order to make the index to easily perform tend to conceal their own production and business operation condition and ability [2]. The responsibility of the different units in the process of enterprise top management make the responsibility index, often bargaining with top management, makes every effort to reduce the unit responsibility index, makes it easy to complete, each unit negotiations ability strong and the weak also makes the ups and downs of between departments.

The problems in the process of responsibility accounting. First, the accounting responsibility does not perform and the financial accounting unification of accounts and cost project, the accounting rules and procedures, carry forward against the relevant expenditure range standard valuation methods and basic work is weak, there is no strict standard and norm, measuring, testing and acceptance, evaluation system, such as no plan unified price system, lack of unity of the original record to fill in, sign, such as transmission, collection, audit system, the responsibility accounting lost the supervision of the financial accounting [3]. Second, internal settlement price, which is the basis for responsibility accounting is not strong, the reliability of internal settlement price formulation must are beneficial to transfer into departments and departments, and cannot exist great differences between the actual price.

The problems in the process of assessment responsibility performance. First of all, the controllability principle is difficult to implement the responsibility accounting, some enterprises in the assessment responsibility performance, do not take the controllability principle, makes the performance indicators it is difficult to reflect the performance of each responsibility unit. As at present, quite a few enterprises serious overcrowding, recessive unemployment exist in different degrees, machinery and equipment capacity and production cannot meet the design ability, such as the waste of resources, causing wages and per unit product such as depreciation of the fixed costs of the improvement, thus affecting the production efficiency of the enterprise, and responsibility for each unit performance indicators caused the influence of different level, make the responsibility accounting system is difficult to effectively play a role. Second, the cost of a single evaluation index is easy to cause adverse incentives [3]. Current responsibility accounting too much emphasis on indicators of lower cost, but in the modern market economy environment, time, quality and efficiency as the foundation of enterprise competition success; The responsibility of the single index also easily lead to various responsibility unit when performing indicators in order to maximize local interests and influence other responsibility unit and the whole interests of enterprises.

Has failed to effectively combine, incentive mechanism cannot play a role. Has the life of responsibility accounting is the organic unification, but the reality economic life has the power to carry out the insufficient, this point is especially obvious in the state-owned enterprises. Despite the bloated, corporate leadership to fire the worker also is very difficult [3]. Though more than 20 years of reform and opening-up, our country enterprise between, between departments, between personal income distribution classes gradually opening, the implementation of responsibility accounting system will definitely be beneficial. But we also have to admit that the income gap of overall enough, especially the management staff at all levels of income and their responsibilities, and the cost of reasonable contribution is still hard to match, this is not conducive to mobilize their enthusiasm, has also not conducive to the together as the basic principle of the formation and development of responsibility accounting system.

\section{Responsibility accounting in the enterprises to use problem solving countermeasures}

According to the enterprise actual situation, rational division of responsibility unit. Under the modern enterprise system, the enterprise independent financial self-sufficiency, becomes the main body of market economy, in the fierce market competition, the enterprise to improve profitability way also is diverse. So enterprises to encourage reducing costs at the same time set up effective incentive internal unit to expand sales, create more profits, improve the efficiency of investment, and reduce the risk of investment mechanism [4]. This requires companies to comply with the requirements of market economy, according to the enterprise scale, production and operation 
of the specific circumstances and the function of internal unit attribute set up in the true sense of a profit center, investment center, giving their economic responsibility of decision-making, in order to improve the enterprise strain capacity, profitability, investment ability, realize enterprise value maximization, each responsibility center has defined rights and responsibilities, and can effectively avoid or reduce the workshop between, between team, and even personal free-rider tendency of opportunism behavior of each other.

Basic work to improve the implementation of responsibility accounting. Enterprises should implement responsibility accounting, must also be a series of basic work, the enterprise must improve all kinds of original records, the norm, the acceptance of measurement management system, internal price system, a variety of quota standards, property material management system, inventory system and standardize the accounting, financial management system [4]; Enterprises to develop means of work, clear background, verify all responsible units take up money and property, material, etc.; Enterprises need to improve the system of internal settlement, each responsibility center according to market laws, the relationship between market introduction of enterprise, to improve the effect of the use of funds.

Speed up to improve the quality of accounting personnel and accounting computerization. To strengthen the enterprise accounting personnel on-the-job training, the responsibility accounting, and accounting computerization, accounting staff continuing education content, people, for the promotion and application of responsibility accounting, foster a batch of can master the application of responsibility accounting and accounting computerization compound talents, on the one hand, not only to make the accounting personnel to master the responsibility accounting basic theory as soon as possible, improve the actual effect, should also be successful experiences on the establishment of a responsibility accounting system as intuitive teaching materials, pays attention to training application ability of accounting personnel [4]. Attaches great importance to the accounting computerization, on the other hand, to popularize and apply in the financial work at the same time, should speed up the development of computerized accounting management functions, from the current auxiliary accounting to participate in the management direction, for the responsibility accounting to provide more detailed, more accurate and faster information.

Set up scientific evaluation system. The enterprise when carries on the performance evaluation must consider its scientific nature, rationality, comprehensive, to different evaluation objects, with different methods. In particular should follow the following principles [5]:

To be helpful for the long-term interests of enterprise. On the operating results of the responsibility center not only in the short term as its advantages and disadvantages of standard, it remains to be seen whether its behavior is conducive to the long-term development of the enterprise.

Absolute index and relative index, the combination of both, if only one-sided emphasis on a, tend to produce adverse effects. For example, the assessment of investment center only to profit as the standard will not be able to understand how investment efficiency; On the basis of investment efficiency and tend to only make investment center refused to those who can reduce profit margins and actually advantageous to the enterprise investment projects.

Combined with the value index value indicators. Can use currency performance is important, but can't or it's hard to use monetary said also to be performance, so as to achieve the fair and reasonable.

Evaluation to exclude responsibility center uncontrollable factors in the evaluation index, responsibility center is only responsible for a part can be controlled.

On the basis of behavioral science, improve the incentive mechanism. Perfect incentive mechanism of enterprise management decision goal through the layers of decomposition, implementation to the various functional departments, various functional departments can around the enterprise overall goal in an orderly way, fruitful continues to run, is the key to realize the goal of enterprise management [5]. Responsibility accounting should be based on the science of behavior, the behavior of the person in charge of fully considering the material and spiritual rewards, according to the behavior of those responsible for perfecting the incentive mechanism. Second, enterprises should according to the actual situation of each responsibility center, according to the daily accounting information, and responsibility for examination and assessment on a regular basis out of appraisal 
report. Appraisal report generally includes responsibility targets and rewards and punishments, contract fulfillment situation. In the evaluation and rewards and punishment, it is a combination of periodic and should be paid attention to a long-term; it should be according to the characteristics of enterprise management and the responsibility center work highlight the main evaluation indexes and the main index by discussion or main index veto. Responsibility center work performance is good or bad in terms of rewards and punishments should be directly linked to economic benefits, through the distribution of income.

\section{Summary}

With modern responsibility accounting is more and more recognition and attention by enterprises and social norms of modern responsibility accounting in theory and practice of the operation will be guided and can give companies more specific and practical guidance. Corporate leadership in order to effectively manage the huge economic organization, it is necessary to take part of the delegation, to mobilize the enthusiasm and initiative of all levels of management, to promote enterprise development and the biggest achievement.

\section{References}

[1] X.Y. Jiang, Extraction responsibility accounting in the enterprise, The application of metallurgical accounting, 2007.vol.8, pp.21- 25.

[2] S.F. Niu The application of responsibility accounting in Chinese enterprise, Education of accounting research, 2013, vol.7, pp.86-89.

[3] Y.J. Duan, Try to talk about responsibility accounting and its application in the modern enterprise system, Fiscal and financial, 2012, vol.4, pp.19-23.

[4] Y.M. Shen, Establish the responsibility accounting system, Perfect enterprise management intelligence development of science and technology and economy, 2005, vol.4, pp.84-87.

[5] R.H. Wang and X.H. Yao, Convergence analysis of responsibility accounting and internal control, Accounting communications, 2011 vol.4, pp.31-35. 